\title{
Quality Evaluation of Selection Oppenheim 4 Rootstock Clones Used to Produce Grapevine Planting Material, Depending on the Applied Agrotechnics
}

\author{
Daniela POPESCU ${ }^{1 *}$, Maria ILIESCU ${ }^{11}$, Maria COMSA ${ }^{1)}$, Dan Gh.CORBEAN ${ }^{2 *}$ \\ ${ }^{1)}$ Reasearch Station for Viticulture and Enology Blaj, 2 Gh. Baritiu Street, 515400 Blaj, Alba Conty, Ro- \\ mania. ${ }^{2}$ SC Jidvei SRL, Jidvei, 33 Garii Street, Alba Conty, Romania \\ ${ }^{*}$ Corresponding authors, e-mails: hodordaniela@yahoo.com,dan.corbean@jidvei.ro
}

Bulletin UASVM Horticulture 71(2) / 2014

Print ISSN 1843-5254, Electronic ISSN 1843-5394

DOI:10.15835/buasvmcn-hort:10675

\begin{abstract}
The implications of various vines practices (trellised or grown flat on the ground) influence the degree of canes maturations. In the present paper are analyzed the implications of various vines practices (using support systems-Romania, without means of support-France) on the maturation degree of canes of different clones belonging Selection Oppenheim 4 Rootstock (SO4) rootstock used in the grafting process. Have been tested rootstock clones of SO4 from France (clones 5, 18, 102, 203, 762) and Romania (clone 4).Carbohydrate content in clones studied recorded values between 13.81-16.07 g\%, these values ranking rootstock clones in category sufficiently matured (between 14 to $16 \mathrm{~g} \%$ ) to good matured (over 16g \%). By using the support system is obtain a good mature stock with a uniform diameter.
\end{abstract}

Keywords: agrotechnical practices, carbohydrates, SO4 rootstock clones

Introduction. An very important criterion in achieving good grafting and finally, a quality grapevine planting material is the maturation degree of the wood (carbohydrate content) of the two partners grafting (scion and rootstock) (Hunter et al., 1996). The processes of rootedness and callus formation are energy-intensive processes that can not be taken over than through hydrolysis of poliglucid located in reserve rootstock cuttings. Therefore, the material with total carbohydrate content below $12 \%$ is rejected from propagating (Iliescu et al., 2012; Corbean, 2011). Worldwide, rootstock mother material is either trellised or grown flat on the ground. When rootstocks are not trellised, the flat shoots mostly form a thick carpet on the ground. Some shoots are therefore fully exposed to sunlight, some only receive diffused sunlight and others are growing in complete shade. This has a direct effect on the reserve and ripeness status of shoots. Shoots therefore do not ripen uniformly and this may eventually lead to varying callus success (Hunter et al., 2004).
Aims. In the present paper are analyzed the implications of various vines practices (using support systems-Romania, without means of support-France) on the maturation degree of canes of different clones belonging SO4 rootstock used in the grafting process.

Materials and Methods. Have been tested rootstock clones of SO4 from biological category Certificate existing in mother plantation from France (clones 5, 18, 102, 203, 762) and Romania (clone 4), the culture system practiced being trellised (SCDVV Blaj - Romania) and without means of support (Morisson Couderc - France). The tests were performed on canes from the harvest 2012 and 2013. Establish the quality of rootstock used for the production of grapevine planting material was made by determining the carbohydrate content (extraction of sugar with ethyl alcohol and starch with perchloric acid and treated with anthrone; was used UV-VIS Spectrophotometer at a wavelength of $620 \mathrm{~nm}$ ), the humidity and the diameter of canes. 


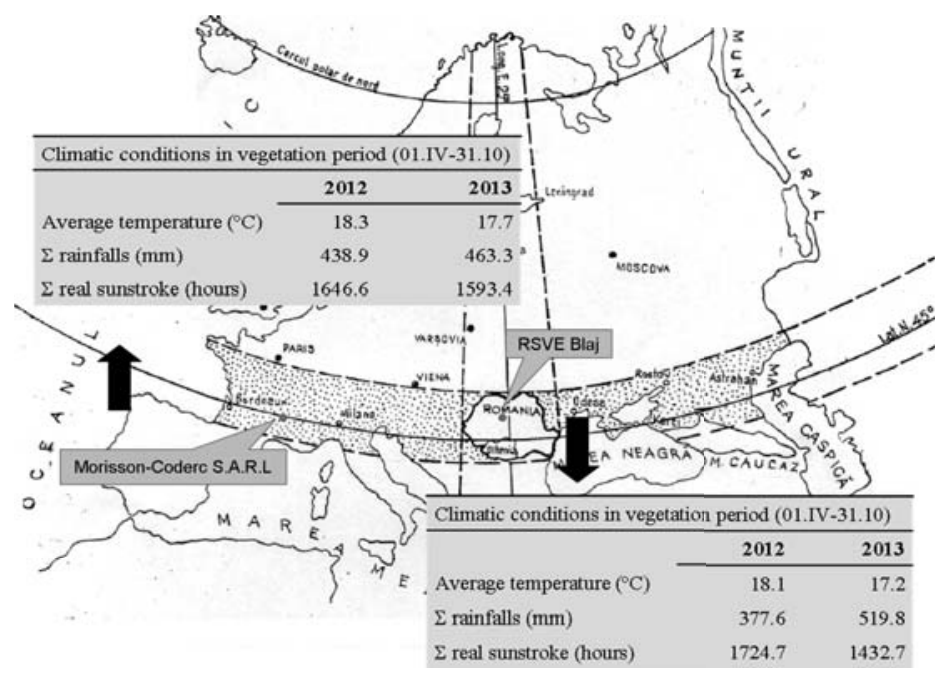

Fig. 1. Geographical position and climatic conditions of the studied rootstocks plantations

Tab. 1. The quality of canes from SO4 rootstock clones

\begin{tabular}{|c|c|c|c|c|c|c|}
\hline Variant & Harvest year & $\begin{array}{l}\text { Canes } \\
\text { diameter } \\
(\mathrm{mm})\end{array}$ & $\begin{array}{l}\text { Humidity } \\
\text { (\%) }\end{array}$ & $\begin{array}{l}\text { Sugar content } \\
\text { (g\%) }\end{array}$ & $\begin{array}{c}\text { Starch content } \\
(\mathrm{g} \%)\end{array}$ & $\begin{array}{c}\text { Total carbohydrates } \\
\text { (g\%) }\end{array}$ \\
\hline \multirow[t]{2}{*}{ Clone 4} & 2012 & $7.23 \pm 0.47$ & $42.2 \pm 1.9 \mathrm{~b}^{\mathrm{a}}$ & $7.30 \pm 0.82 \mathrm{c}$ & $8.36 \pm 0.49 a$ & $15.65 \pm 1.26 \mathrm{ab}$ \\
\hline & 2013 & $8.16 \pm 0.83$ & $47.1 \pm 1.0 \mathrm{a}$ & $10.98 \pm 0.97 a$ & $3.10 \pm 0.46 \mathrm{e}$ & $14.08 \pm 1.09 c$ \\
\hline \multirow{2}{*}{ Clone 5} & 2012 & $8.97 \pm 1.66$ & $39.9 \pm 1.5 \mathrm{~cd}$ & $10.37 \pm 0.49 \mathrm{ab}$ & $5.70 \pm 0.20 \mathrm{~b}$ & $16.07 \pm 0.35 \mathrm{a}$ \\
\hline & 2013 & $7.16 \pm 0.01$ & $39.3 \pm 0.1 \mathrm{~d}$ & $10.42 \pm 0.01 \mathrm{ab}$ & $3.39 \pm 0.01 \mathrm{de}$ & $13.81 \pm 0.01 \mathrm{c}$ \\
\hline \multirow[t]{2}{*}{ Clone 762} & 2012 & $8.37 \pm 3.01$ & $42.4 \pm 1.8 \mathrm{~b}$ & $10.10 \pm 0.66 \mathrm{~b}$ & $4.30 \pm 1.01 \mathrm{~cd}$ & $14.40 \pm 1.47 \mathrm{bc}$ \\
\hline & 2013 & $7.77 \pm 0.37$ & $41.4 \pm 0.9 \mathrm{bc}$ & $10.73 \pm 0.12 \mathrm{ab}$ & $4.31 \pm 0.81 \mathrm{~cd}$ & $15.05 \pm 0.69 \mathrm{abc}$ \\
\hline Clone 18 & 2013 & $7.32 \pm 0.01$ & $39.8 \pm 0.1 \mathrm{~cd}$ & $10.51 \pm 0.01 \mathrm{ab}$ & $5.30 \pm 0.01 b c$ & $15.81 \pm 0.01 \mathrm{ab}$ \\
\hline Clone 102 & 2013 & $8.11 \pm 0.01$ & $43.4 \pm 0.1 \mathrm{~b}$ & $9.83 \pm 0.01 \mathrm{~b}$ & $5.04 \pm 0.01 \mathrm{bc}$ & $14.87 \pm 0.01 \mathrm{abc}$ \\
\hline Clone 203 & 2013 & $7.56 \pm 0.53$ & $41.6 \pm 0.9 \mathrm{bc}$ & $10.55 \pm 0.58 \mathrm{ab}$ & $4.62 \pm 0.65 c$ & $15.17 \pm 0.08 \mathrm{abc}$ \\
\hline \multicolumn{2}{|c|}{ Sig. } & $\mathrm{p}<0.000$ & $\begin{array}{c}\mathrm{p}<\underset{* * *}{0.000} \\
\end{array}$ & $\mathrm{p}<\underset{* *}{0.000}$ & $\mathrm{p}<\underset{* * *}{0.000}$ & $\mathrm{p}<\underset{* * *}{0.000}$ \\
\hline Year & & ns & $*$ & $* * *$ & $* * *$ & $* *$ \\
\hline Clone x Year & & ns & $* * *$ & $* * *$ & $* * *$ & $*$ \\
\hline
\end{tabular}

${ }^{a}$ Average value \pm standard deviation $(\mathrm{n}=3$ ). Different letters are significantly different for $\mathrm{P} \leq 0.05$. The difference between any two values, followed by at least one common letter, is insignificant. ${ }^{b}$ Significance of variety, year of harvest and interaction variety $\mathrm{x}$ year was tested for $\mathrm{P}$ $\leq 0.05(*), \mathrm{P} \leq 0.01(* *)$, and $\mathrm{P} \leq 0.001(* *)$.

Results and Discussion. Regardless of culture system practiced rootstock the diameter of canes at all clones tested have recorded values between 7.23-8.97 $\mathrm{mm}$, values that correspond into force STAS. The influence of ecoclimatice factors (Fig. 1) as well as variety of clonale had no significant effect on the diameter; the differences between clones were given by the green works applied in culture (Tab. 1). Both the genotype and climatic conditions of the experimental years had significant effects on carbohydrate content. It was found that the highest effect was given by the clonale variety. Carbohydrate content in clones studied recorded values between 13.81-16.07 g\%. According to Hunter et al. (2004) and Iliescu et al. (2012) these values ranks rootstock clones in category sufficiently matured (between 14 to 16 g\%) to good matured (over 16g \%).
Conclusion. By using the support system is obtain a good mature stock with a uniform diameter; carbohydrate accumulation may be influenced by performing green work during vegetation period.

\section{REFERENCES:}

1. Corbean DG (2011). New technologies for producing grapevine planting material, in Târnave Vineyard. PhD THESIS, UASMV Cluj-Napoca.

2. Hunter JJ, Le Roux DJ, Volschenk CG (1996). Reserve nutrient status of Vitis graft material as related to callus success and growth during the callus period. In: J.M. Rantz (ed.). Proc's Int. Symp. Table Grape Production, 28 - 29 June 1996, Anaheim, California. pp. II-71-73.

3. Hunter JJ, Volschenk CG, Le Roux DJ, Fouche GW, Adams L (2004). Plant material quality-a compilation of research. Ed. ARC-Infruitec-Nietvoorbij, South Africa.

4. Iliescu M, Popescu D, Comşa M (2012). Studies on quality of rootstocks in the viticultural centre Blaj. Bulletin UASMV Horticulture, 69(1):395. 